\title{
Infeksi Jamur Sistemik pada Pasien Immunocompromised
}

\author{
Djajadiman Gatot
}

\begin{abstract}
Dalam keadaan normal relatif sedikit spesies jamur yang patogenik. Akan tetapi pada beberapa keaaan tertentu seperti defisiensi imun (immunocompromised) beberapa spesies jamur dapat menyebabkan infeksi, terutama pada pasien dengan keadaan defisiensi imun (immunocompromised). Beberapa kondisi yang dapat menimbulkan keadaan immunocompromised antara lain ialah neutropenia, adanya kerusakan pada imunitas seluler dan humoral, perubahan pada sawar fisik, gizi buruk, adanya obstruksi dan perubahan flora bakteri. Secara klinis infeksi jamur dibagi menurut tempat infeksi dan jenis patogenesisnya. Keadaan yang perlu mendapat perhatian khusus ialah infeksi jamur sistemik karena dapat meningkatkan angka mortalitas. Ada beberapa faktor yang menyebabkan jumlah kasus infeksi jamur sistemik bertambah pada kelompok pasien yang berbeda. Kelompok pasien ini perlu diketahui sehingga diagnosis dapat ditegakkan dan pencegahan infeksi jamur dapat dilakukan sehingga diharapkan dapat menurunkan angka morbiditas dan moralitas.
\end{abstract}

Kata kunci: jamur, immunocompromised, infeksi jamur sistemik.

$C$

eadaan immunocompromised yaitu gangguan fungsi imunitas selular dan humoral yang sebenarnya dan dapat berlangsung cukup lama, adalah sebagai akibat pengobatan dengan imunosupresan atau pun akibat proses penyakit tertentu. Pasien dengan keadaan immunocompromised menderita defisiensi imun dan merupakan sasaran utama berbagai penyakit infeksi yang disebabkan bakteri, jamur, virus atau infeksi nosokomial. ${ }^{1,2}$

Berbagai kondisi yang menimbulkan defisiensi imun $^{2}$

\section{Neutropenia}

Neutropenia didefinisikan apabila jumlah neutrofil absolut $<500 \mathrm{sel} / \mathrm{uL}$ untuk pasien dengan tumor padat atau $<1000 \mathrm{sel} / \mathrm{ul}$ untuk pasien leukemia. Apabila

Alamat korespondensi:

Dr. Djajadiman Gatot, Sp.A(K).

Kepala Subbagian Hematologi. Bagian Ilmu Kesehatan Anak FKUIRSCM. Jl. Salemba no. 6. Jakarta 10430.

Telepon: 021-319 01170. Fax. 021-390 7743. jumlah neutrofil menurun secara bermakna dan masa neutropenia cukup lama, maka risiko terjadinya infeksi oleh bakteri, jamur, virus atau mikroorganisme oportunistik akan meningkat secara nyata. Khusus pasien yang sebelumnya telah mendapat kemoterapi atau radioterapi akan lebih peka terhadap infeksi.

\section{Kerusakan pada imunitas selular dan humoral}

Iradiasi, sitostatik dan kortikosteroid adalah penyebab gangguan dan perubahan pada sistem imunitas selular. Sedangkan sistem imunitas humoral yang dalam keadaan normal akan bereaksi dengan melakukan opsonisasi bakteri dan membuat antibodi bakterisid akan mengalami gangguan apabila organ pembentuknya mengalami kerusakan (misalnya splenektomi).

\section{Perubahan pa da sawar fisik}

Gangguan pada sawar fisik seperti kulit, saluran cerna, saluran kemih, mukosa saluran napas selama kemoterapi 
atau pun tindakan invasif akan merupakan tempat masuknya mikroorganisme ke dalam tubuh. Hal lain yang dapat merusak sawar pelindung ialah kateter intravena atau kateter saluran kemih, alat intubasi, tempat bekas suntikan, aspirasi sumsum-tulang, ektravasasi atau operasi.

\section{Status nutrisi/gizi}

Gizi yang baik penting untuk mempertahankan sistem imunitas selular, karena telah diketahui bahwa gizi buruk menyebabkan penurunan fungsi limfosit dan fagositosis seperti halnya kesembuhan sawar kulit dan mukosa.

\section{Obstruksi}

Obstruksi pada saluran napas akan meningkatkan risiko infeksi oleh bakteri anaerob, demikian pula obstruksi pada saluran kemih akan meningkatkan risiko infeksi oleh bakteri tertentu. Oleh karena itu keadaan ini harus mendapat perhatian khusus pada pasien dengan neutropenia atau immunocompromised.

\section{Disfungsi susunan saraf pusat}

Gangguan susunan saraf pusat yang disebabkan tumor primer otak atau pun oleh metastasis mengakibatkan gangguan pada mekanisme protektif. Misalnya, hilangnya refleks muntah, dapat menyebabkan pneumonia aspirasi atau gangguan miksi dapat menyebabkan timbulnya infeksi saluran kemih.

\section{Perubahan flora bakteri}

Sebagian besar kejadian infeksi disebabkan oleh bakteri yang terdapat dalam tubuh pasien sendiri. Oleh karena itu kolonisasi bakteri yang ada dalam saluran napas atau pun saluran cerna perlu mendapatkan perhatian khusus. Hal ini juga bergantung kepada keadaan neutropenia. Dua faktor yang menentukan kolonisasi bakteri ialah penggunaan antibiotik yang ekstensif dan jenis bakteri atau jamur yang ada di ruang rawat tertentu seperti unit perawatan intensif atau bangsal onkologi. Penggunaan antibiotik spektrum-luas dapat mengubah flora anaerob dalam usus dan menyebabkan meningkatnya kepekaan terhadap mikroorganisme yang lebih virulen seperti $P$. Aeruginosa.

\section{Jamur Patogen pada Manusia ${ }^{4}$}

Dalam keadaan normal relatif sedikit spesies jamur yang patogenik, walaupun demikian beberapa spesies yang dapat menyebabkan infeksi menjadi penting untuk diperhatikan. Secara umum jamur adalah organisme yang hidup bebas di mana-mana dan apabila terjadi infeksi oleh jamur pada seseorang yang sehat, biasanya berasal dari lingkungannya dan masuk ke dalam tubuh secara inhalasi, tertelan, ataupun secara langsung. Dari sekitar 50.000-200.000 spesies jamur yang telah diketahui, hanya kurang dari 200 jenis jamur saja yang tercatat dapat menimbulkan penyakit pada manusia. Namun demikian pada beberapa keadaan tertentu, lebih banyak lagi jenis jamur yang dapat menimbulkan penyakit; misalnya pada immunocompromised, infeksi dapat disebabkan oleh jamur yang dalam keadaan sehat hidup dalam mulut atau saluran cerna tanpa menimbulkan penyakit. Selain itu dapat juga disebabkan oleh jamur yang berada di sekitarnya.ecara klinis, infeksi jamur dibagi menurut tempat infeksi dan jenis patogenisitasnya, yaitu:

- dangkal (superfisial): tetap berada di permukaan tubuh

- dalam: menyerang jaringan atau organ yang lebih dalam

- jamur oportunistik (pada keadaan immunocompromised)

- patogen sejati, dapat menimbulkan penyakit pada orang sehat.

\section{Infeksi superfisial ${ }^{4}$}

Infeksi jamur superfisial terbatas pada bagian luar tubuh seperti kulit, rambut, kuku dan selaput lendir dan merupakan jenis infeksi yang paling sering dijumpai namun umumnya tidak berat. Penyebabnya biasanya ialah golongan dermatofit, seperti spesies Microsporum, Trichophyton Epidermophyton dan Candida. Spesies Candida, khususnya Candida albicans, merupakan jamur yang sangat patogen pada manusia.

\section{Infeksi subkutis ${ }^{4}$}

Infeksi jamur subkutis terdapat di bawah kulit. Biasanya jamur menembus kulit melalui tempat luka atau trauma 
Tabel 1. Beberapa jenis jamur patogen pada manusia ${ }^{4}$

\begin{tabular}{lll}
\hline Jamur patogen & Struktur & Jenis infeksi \\
\hline Spesies Candida & ragi, hifa, pseudohifa & superfisial, sistemik \\
Trichophyton rubrum & jaringan & superfisial \\
Epidermophyton floccosum & jaringan & superfisial \\
Microsporum audouinii & jaringan & superfisial \\
Sporothrix schenckii & dismorfik & subkutis \\
Spesies Aspergillus & jaringan & sistemik \\
Cryptococcus neoformans & ragi & sistemik \\
Histoplasma capsulatum & dismorfik & sistemik \\
Coccidioides immitis & dismorfik & sistemik \\
Blastomyces dermatidis & dismorfik & sistemik \\
Paracoccidioides brasiliensis & dismorfik & sistemik \\
Spesies Mucorales & jaringan & sistemik \\
\hline
\end{tabular}

dan menyebabkan infeksi lokal yang kemudian menyebar ke jaringan di sekitarnya dan bahkan dapat menembus tulang. Contoh infeksi jamur subkutis ialah chromoblastomycosis dan madura foot (mycetoma). Sporothrix schenckii, suatu jenis jamur yang biasanya terdapat pada tanaman, dapat menyebabkan abses subkutis dan ulkus bila masuk ke dalam kulit akibat tusukan duri atau kerikil.

\section{Infeksi sistemik ${ }^{3,4}$}

Infeksi jamur sistemik dimulai dari infeksi lokal atau dari koloni jamur dalam saluran cerna atau selaput lendir lain yang kemudian menyebar ke berbagai alat tubuh lain. Infeksi dapat juga dimulai dari paru karena jamur yang terhisap. Jamur yang dapat menimbulkan infeksi sistemik dibagi dalam dua kelompok patogen, ialah jamur patogen oportunistik dan jamur patogen sejati. Jamur patogen oportunistik terdiri dari organisme yang kurang virulen dan beradaptasi baik, contohnya ialah spesies Candida dan Aspergillus. Apabila organisme ini masuk ke tubuh pejamu (hospes) dengan kondisi yang sangat lemah atau immunocompromised, maka infeksi yang terjadi biasanya berat dan tidak jarang mengancam jiwa. Tetapi spesies Candida biasanya juga menimbulkan infeksi yang tidak berat. Jamur patogen sejati hanya merupakan bagian kecil saja dari organisme yang dapat menimbulkan infeksi pada pejamu (hospes) tanpa adanya predisposisi tertentu, contoh Cryptococcus immitis dan Histoplasma capsulatum. Organisme ini biasanya dapat menyesuaikan diri untuk hidup dalam tubuh hospes.
Pada sebagian besar kasus, infeksi dengan jamur patogen sejati biasanya ringan dan asimtomatik. Umumnya terjadi di daerah endemik. ${ }^{4}$

Infeksi jamur sistemik (IJS) merupakan keadaan klinis yang sangat serius. Di Eropa dan Amerika Serikat, peningkatan yang cepat angka kejadian IJS telah membuat jamur sebagai organisme patogen ke-empat atau ke-lima yang sering dijumpai dalam klinik.

Hal-hal yang menyebabkan peningkatan IJS ${ }^{3-5}$

1. Perubahan cara pengobatan. Beberapa tahun terakhir ini, perbaikan di bidang perawatan suportif medik dan bedah telah meningkatkan jumlah pasien yang dapat selamat dari penyakit ataupun trauma berat. Kemajuan ini melibatkan berbagai cara penunjang kehidupan, penggunaan antibiotik spektrum luas, berbagai janie kateter dan nutrisi parenteral. Kemajuan di bidang teknologi medik telah membuat operasi transplantasi dan kemoterapi menjadi rutin.

2. Perubahan pasien. Meningkatnya jumlah pasien immunocompromised yang meninggal karena infeksi jamur yang sebelumnya telah dapat selamat dari infeksi bakteri dan penyakit dasarnya ataupun trauma. Pasien dengan operasi abdomen atau yang menderita kanker atau sedang dalam transplantasi organ atau sumsum-tulang, pasien HIV dn AIDS, atau pasien di ruang perawatan intensif, merupakan pasien dengan risiko infeksi tinggi. Di samping itu kenaikan jumlah populasi manusia lanjut usia mempunyai hubungan dengan kenaikan insidens IJS nosokomial dan dari lingkungan.

3. Perubahan patogen. Sebagai contoh di Amerika 
Serikat, kasus IJS telah meningkat dari 75\% hingga lebih dari 400\% sejak awal 1980-an, dan merupakan $10-15 \%$ dari seluruh infeksi nosokomial sistemik. Sebagian besar IJS disebabkan spesies Candida dan Calbicans merupakan patogen terbanyak pada pasien dengan kandidemia. Namun beberapa tahun belakangan ini telah terjadi pergeseran yang cukup besar ke arah spesies non-albicans sebagai penyebab IJS. Walaupun tidak sesering dan seinvasif kandidosis, aspergilosis nosokomial juga semakin banyak menimbulkan penyakit berat maupun kematian di antara pasien dengan gangguan fungsi imun, terutama pasien dengan immunocompromised yang berat, seperti pada transplantasi sumsum-tulang atau organ dan kemoterapi intensif.

\section{Pentingnya infeksi jamur sistemik $\mathbf{k}^{3,4}$}

Makin meningkatnya infeksi jamur dikaitkan dengan peningkatan bermakna angka kematian dan bertambahnya masa perawatan di rumah sakit. Selain itu infeksi jamur yang invasif disertai diseminasi, merupakan penyebab morbiditas dan mortalitas yang cukup besar (CMR: 25$60 \%$ ), walaupun bergantung pula pada populasi pasien.

\section{Infeksi jamur sistemik pada kelompok pasien risiko tinggi $i^{1-4}$}

Adanya kombinasi faktor risiko, menyebabkan jumlah kasus IJS berat bertambah pada beberapa kelompok pasien yang berbeda. Sebagai konsekuensinya, klinisi pada berbagai sub-disiplin akan menghadapi kasus IJS baik sesekali ataupun secara rutin. Peningkatan angka kejadian dan perubahan pola penyakit infeksi tampaknya akan menyebabkan IJS bertambah sering di kemudian hari. ${ }^{3}$

\section{Kelompok pasien risiko tinggi terdapat di bidang ${ }^{1,2,4}$}

Onkologi/hematologi; kanker dan kemoterapinya secara langsung dapat merusak sistem imun dan meningkatkan kejadian infeksi.

Unit perawatan intensif; pada umumnya pasien di unit ini berisiko tinggi karena pemakaian antibiotik spektrum luas dan karena kerusakan pada kulit atau selaput lendir akibat tindakan anastomosis, trauma, gizi buruk, hipotensi, pengobatan dengan steroid, dan penggunaan alat invasif.

Unit transplantasi sumsum-tulang atau organ; pada saat berlangsungnya transplantasi dan selama pemulihan, pasien akan mengalami keadaan immunocompromised yang cukup berat dan lama.

Pasien HIV dan AIDS; keadaan defisiensi imun pada AIDS menyebabkan sekitar 90\% pasiennya setidaknya sekali mengalami infeksi jamur selama perjalanan penyakitnya yang berkisar dari ringan (pada mukosa) sampai IJS berat. Umumnya 10-20\% IJS berakhir fatal.

Lain-lain; penyalahgunaan obat terlarang khususnya melalui suntikan dan dengan cara yang tidak steril meningkatkan risiko terjadinya infeksi HIV dan jamur.

\section{Diagnosis infeksi jamur ${ }^{3,4}$}

Diagnosis infeksi jamur, khususnya pada pasien immunocompromised merupakan hal yang sulit bagi para klinisi. Diagnosis laboratorium infeksi jamur pada pasien immunocompromised melalui satu atau lebih pendekatan seperti (i) pemeriksaan mikroskopik seksama terhadap sekret saluran nafas, (ii) isolasi organisme, (iii) deteksi antibodi atau antigen jamur, dan (iv) pembuktian invasi jamur secara histopatologi.

\section{Pencegahan infeksi jamur ${ }^{3,4}$}

Pada umumnya pencegahan infeksi jamur cukup sulit. Usaha yang penting ialah menghindari faktor predisposisi untuk infeksi. Kebersihan lingkungan yang baik diperlukan untuk menghindari infeksi terutama aspergillosis. Perhatian khusus perlu diberikan untuk prosedur invasif, pada keadaan neutropenia, dianjurkan pemakaian dua jenis antibiotik atau lebih untuk mencegah terjadinya kandidemia.

\section{Profilaksis terhadap infeksi jamur ${ }^{1,3-5}$}

Keinginan kuat untuk membuat suatu regimen profilaksis untuk menurunkan angka kematian akibat infeksi jamur pada pasien dengan neutropenia, khususnya pada transplantasi sumsum-tulang, telah timbul dan mendapat kesepakatan. Hasil yang cukup baik untuk profilaksis aspergilosis dicapai dengan pemberian amphotericin $B$ (aerosol, intravena, liposomal) 
dan itraconazole oral. Terhadap spesies kandida mencegah terjadinya koloni di daerah orofaring merupakan hal penting untuk mencegah terjadinya kandidosis sistemik. Berbagai laporan menyebutkan bahwa fluconazole $(100 \mathrm{mg} /$ hari) lebih efektif daripada nystatin dan azole yang lain (clotrimazole, ketokonazole) untuk mencegah candidosis daerah orofaring pada pasien immunocompromised. Pemakaian itraconazole dengan dosis yang sama secara oral memberikan hasil yang lebih baik. ${ }^{1,5}$

Selain itu obat anti-jamur dapat diberikan secara empiris, khusus untuk pasien dengan neutropenia dan mengalami demam yang berkepanjangan walaupun telah diberi antibiotik berspektrum luas. Pada pasien seperti ini biasanya sulit untuk diketahui apakah mereka juga menderita infeksi oleh jamur. Dasar penggunaan antijamur secara empiris ialah (i) diagnosis antemortem untuk penyakit jamur yang menyebar, sulit ditegakkan pada pasien immunocompromised, (ii) menunda pengobatan anti-jamur, berarti memberi kesempatan untuk penyebaran penyakit, sehingga apabila pengobatan segera diberikan dapat mengurangi kejadian infeksi jamur pada pasien immunocompromised, (iii) untuk mengidentifikasi pasien yang mempunyai risiko tinggi terhadap jamur invasif. Pasien dengan neutropenia yang mengalami demam menetap walaupun telah mendapat antibiotik selama 4-7 hari, cenderung menderita infeksi oleh jamur. Pengobatan anti-jamur secara empiris diharapkan dapat memberikan dua keuntungan yaitu menekan tumbuh lampau jamur yang timbul bersama dengan penggunaan antibiotik berspektrum luas dan pengobatan dini infeksi jamur yang subklinis dan terlokalisir. ${ }^{3-5}$

\section{Daftar Pustaka}

1. Freifeld AG, Hathorn JW, Pizzo PA. Infectious complications in the pediatric cancer patient. Dalam: Pizzo PA, Poplack DG, penyunting. Principles dan practice of pediatric oncology. Edisi kedua. philadelphia: Lippincott Co. 1989.h. 987-1019.

2. Irvin RJ, Koeller JM. Oncologic emergencies: infection in the neutropenic or immunocompromised patient. Dalam: Weiss GR, penyunting. A lange medical book: clinical oncology. London: Prentice-Hall International Inc. 1993.h. 355-69.

3. Richardson MD, Kokki MH. Diagnosis and prevention of fungal infection in the immunocompromised patient. Blood Reviews 1998; 12:1-14.

4. Janssen Pharmaceutica. Systemic fungal infection. Training monograph. Tahun 1999.

5. Working Party of the British Society for Antimicrobial Chemoteraphy. Working Party Report: Therapy of deep fungal infection in haematological malignancy. J Antimicrobiol Chemoth 1997; 40:779-88. 